\title{
Original
}

\section{Antimicrobial Characteristics of Bis-quaternary Ammonium Compounds Possessing a $p$-Phenylene Group in Their Spacer Chains}

\author{
AKIHIRO SHIRAI, TAKUYA MAEDA, ICHIRO HARA, \\ AZUMI YOSHINARI, HIDEAKI NAGAMUNE AND HIROKI KOURAI* \\ Department of Biological Science and Technology, Faculty of Engineering, \\ The University of Tokushima, Minamijosanjima-cho, Tokushima 770-8506, Japan
}

Received 28 February 2003/Accepted 14 July 2003

\begin{abstract}
Phenylene-bis-quaternary ammonium compounds (Ph-bis-QACs), 4,4'-(p-xylylenedithio) bis (1-alkylpyridinium iodide)s, $N, N$ '-p-phenylenebis (1-alkyl-4-carbamoylpyridinium bromide) $s$ and 4,4'- (terephthaloylamino) bis (1-alkylpyridinium bromide) s composed of two pyridinium salt groups linked by a $p$-phenylene spacer chain were evaluated for their antimicrobial characteristics. We also compared the activities of these compounds with those of Methylene-bisquaternary ammonium compounds (M-bis-QACs), 4,4'-(1,6-hexamethylenedithio) bis (1alkylpyridinium iodide) $s, N, N$ '-hexamethylenebis (4-carbamoyl-1-alkylpyridinium iodide) $s$ and 4,4'-(tetramethylenedicarbonyldiamino) bis(1-alkylpyridinium iodide)s connected by a methylene spacer chain, and investigated the structure-activity relationship in a bis-QAC. Three Ph-bis-QACs exhibited a high and constant bactericidal activity with a carbon number from $n=8$ to $n=18$, and a wide-ranging and effective antimicrobial activity against both bacteria and fungi. The antibacterial activities of Ph-bis-QACs were higher than those of M-bis-QACs by converting the methylene spacer chain of M-bis-QACs to a $p$-phenylene spacer chain. Moreover, while the activities of M-bis-QACs were influenced by the electron density of ammonium nitrogen, the activities of Ph-bis-QACs were not dependent on that. Therefore, these results suggested that the antibacterial activity of a bis-quaternary ammonium compound (bisQAC) was strengthened more by decreasing the number of rotation axes in the spacer chain rather than changing the electron density of ammonium nitrogen and by increasing the rigid property of molecule structure, and that the steric structure of a bis-QAC is a significant factor influencing the antimicrobial activity of a bis-QAC.
\end{abstract}

Key words : Bis-quaternary ammonium compound/Antimicrobial activity/Structure-activity relationship.

\section{INTRODUCTION}

Surfactants have been designed and synthesized by many chemists worldwide. Quaternary ammonium compounds (QACs) are one of the surfactants which are used as their most representative antimicrobial agent. Conventional single-chain QACs called monoQACs have one ammonium head and one alkyl chain

${ }^{*}$ Corresponding author. Tel: +81-88-656-7408, Fax : +8188-656-9148. per molecule. These mono-QACs have been studied for their bactericidal mechanism (Baley et al., 1977; Devinsky et al., 1991 and 1996) and the quantitative structure-activity relationship (Kourai et al., 1994 and 1995; Maeda et al., 1996; Okazaki et al., 1996). BisQACs are a new generation of QACs which have two ammonium heads and two long alkyl chains per molecule by linking two ammonium groups with a methylene spacer chain. Most of the surface active properties of bis-QACs such as the critical micellization concentration and the aggregation 
behavior are superior to the corresponding properties of mono-QACs (Menger and Keiper, 2000; Menger and Littau, 1993; Zana and Talmon, 1993), and moreover, bis-QACs exhibit remarkably high antimicrobial activities (Devinsky et al., 1985; Diz et al., 1994; Menger and Keiper, 2000). Also studies regarding the synthesis, the surface active properties and the biological properties of an amino acid-based bis (Args) consisting of two symmetrical long chain $N^{\alpha}$-acyl-L-arginine residues have been published (Perez et al., 1996, 1998, and 2002). We have described the syntheses, the antimicrobial activities, the characteristics and the deodorant properties of novel bis-QACs (Maeda et al., 1998, 1999a, and 1999b; Okazaki et al., 1997c; Yoshida et al., 2000 and 2001), but studies on the structure-activity relationship of bisQACs are scarce. We have especially reported on bisQACs named Methylene-bis-quaternary ammonium compounds (M-bis-QACs) which are built up from two ammonium salt residues through a methylene spacer chain. It was presumed that in aqueous solution, M-bis-QACs, composed of the methylene group having some single bonds, are probably folded at the methylene spacer chain and that two ammonium heads approach each other. Therefore we suggested that change in the steric structure of M-bis-QACs influences the antimicrobial activity of a bis-QAC.

In this study, we noted the structure of the spacer chain in bis-QACs and built up three Phenylene-bisquaternary ammonium compounds (Ph-bis-QACs). Three Ph-bis-QACs have a $p$-phenylene group instead of the methylene spacer chain of M-bis-QACs, which enables us to expect the unfolded structure of Ph-bisQACs at their spacer chains in aqueous solution. That is, the Ph-bis-QACs are regarded as molecules possessing a rigid structural property. In this paper, we report the antimicrobial characteristics of three $\mathrm{Ph}$ bis-QACs possessing a $p$-phenylene group at their spacer chains, 4,4'-( $p$-xylylenedithio) bis (1alkylpyridinium iodide)s (4DTBP-X,n) (Kourai, H., Maeda, T., and Yoshida, M. (2000) Japanese Patent Open, No. 95763), N,N'-p-phenylenebis (1-alkyl-4carbamoylpyridinium bromide)s (4BCAP-P,n) and 4,4'-(terephthaloylamino) bis (1-alkylpyridinium bromide)s (4PABP-P,n) (Kourai, H., Maeda, T., Yoshida, M., Kunikata, T., and Tsuchitani, K. (2000) Japanese Patent Open, No. 136185). The antimicrobial characteristics of Ph-bis-QACs were compared with those of M-bis-QACs possessing a methylene spacer chain such as $4,4^{\prime}-(1,6-$ hexamethylenedithio) bis (1-alkylpyridinium iodide)s (4DTBP-6,n) (Maeda et al., 1998; Okazaki et al., 1997c), N,N'-hexamethylenebis (4-carbamoyl-1alkylpyridinium iodide)s (D-38-n) (Yoshida et al.,
2000) and 4,4'-(tetramethylenedicarbonyldiamino) bis (1-alkylpyridinium iodide)s (D-136-n) (Yoshida et al., 2001) instead of the $p$-phenylene spacer chain of Ph-bis-QACs, and the structure-activity relationship of a bis-QAC was investigated.

\section{MATERIALS AND METHODS}

\section{Chemicals}

All chemicals for the syntheses of compounds were reagent grade commercial materials and used without further purification. Ph-bis-QACs possessing a $p$ phenylene group in their spacer chains, 4DTBP-X,n [Kourai, H., Maeda, T., and Yoshida, M. (2000) Japanese Patent Open, No. 95763], 4BCAP-P,n and 4PABP-P,n [Kourai, H., Maeda, T., Yoshida, M., Kunikata, T., and Tsuchitani, K. (2000) Japanese Patent Open, No. 136185], were synthesized according to Japanese patent opens. M-bis-QACs for comparison such as 4DTBP-6,n (Okazaki et al., 1997c),

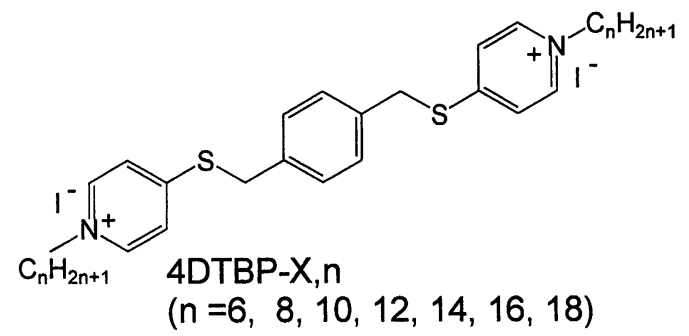

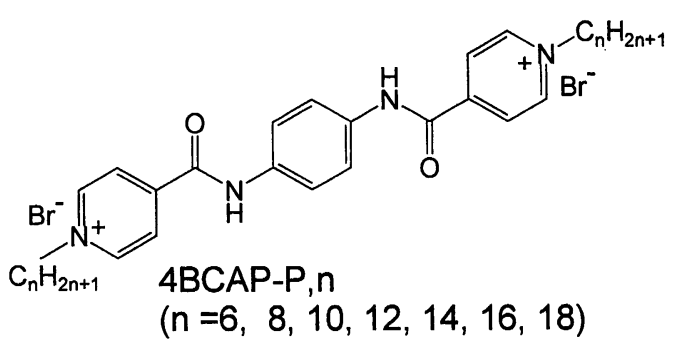

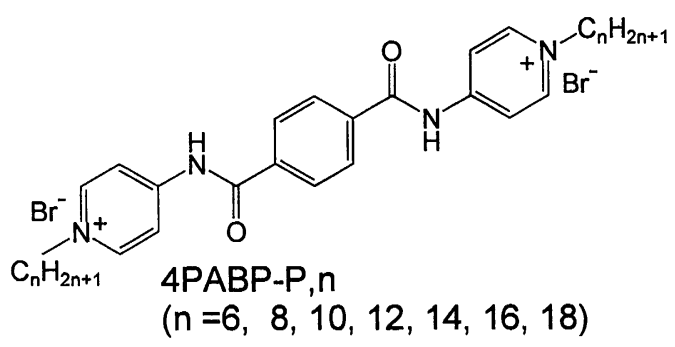

FIG. 1. Chemical structures of Ph-bis-QACs, 4,4'-( $p$ xylylenedithio) bis (1-alkylpyridinium iodide)s (4DTBP-X, n), $\quad N, N^{\prime}-p$-phenylenebis (1-alkyl-4-carbamoylpyridinium bromide) $s$ (4BCAP-P,n) and 4,4'-(terephthaloylamino) bis (1-alkylpyridinium bromide)s (4PABP-P, n). The abbreviation, $\mathrm{n}$, indicates the carbon number of the alkyl chain ( 6 , $8,10,12,14,16$ or 18 ). 


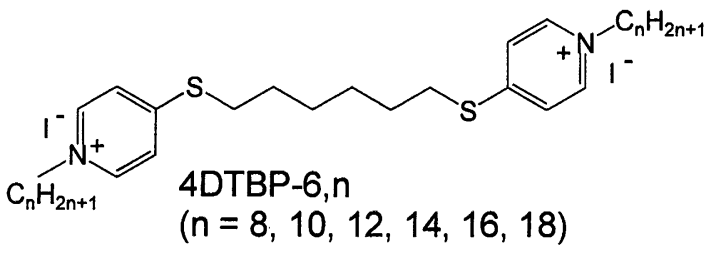

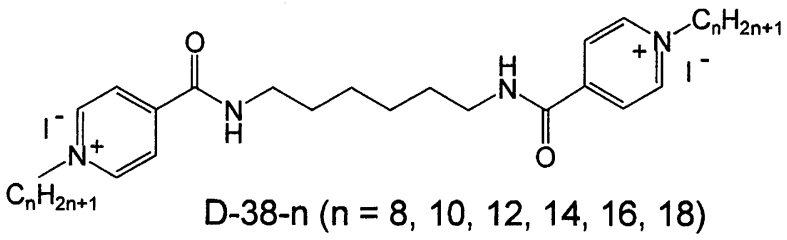

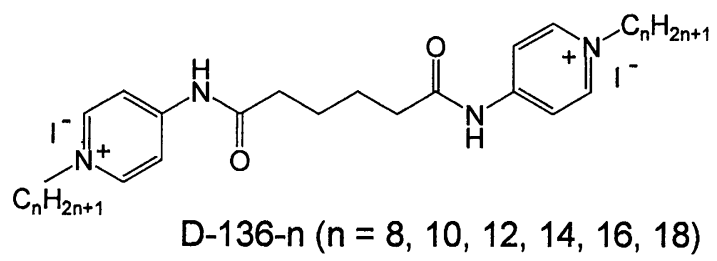

FIG. 2. Chemical structures of comparative compounds (M-bis-QACs), 4,4'-(1,6-hexamethylenedithio) bis (1-alkyIpyridinium iodide) S (4DTBP-6,n), $N, N^{\prime}$-hexamethylenebis (4-carbamoyl-1-alkylpyridinium iodide) s (D-38-n) and 4,4'(tetramethylenedicarbonyldiamino) bis (1-alkylpyridinium iodide) s (D-136-n). The abbreviation, $n$, indicates the carbon number of the alkyl chain $(8,10,12,14,16$ or 18$)$.

D-38-n (Yoshida et al., 2000) and D-136-n (Yoshida et al., 2001) which have a methylene group in the spacer chain were synthesized as described before. The abbreviation, $n$, indicates the carbon number of the alkyl chain. The purity and chemical structure of the synthesized compounds were checked by thinlayer chromatography with a reversed phase, measurement of melting points, elemental analysis and proton nuclear magnetic resonance ('H-NMR) spectra as reported earlier (Maeda et al., 1999b).

The chemical structures of Ph-bis-QACs such as 4DTBP-X, n, 4BCAP-P, $n$ and 4PABP-P, n, and of 4DTBP-6,n, D-38-n and D-136-n as the M-bis-QACs used for comparison are shown in Fig. 1 and 2, respectively.

\section{Microbes, cultivation and preparation}

Except when noted, Escherichia coli K12 W3110 was employed for the experiments. Bacteria and fungi were prepared according to a previous report (Maeda et al., 1999b).

\section{Antimicrobial activity}

The minimum bactericidal concentration (MBC) and minimum inhibitory concentration (MIC) of antimicrobials were measured according to a standard broth dilution method (Okazaki et al., 1997). Bactericidal activity was defined as $\log \mathrm{MBC}^{-1}$.

\section{RESULTS AND DISCUSSION}

\section{Effect of alkyl chain length on the antibacterial activity of Ph-bis-QAC derivatives, and compari- son of their antibacterial activity with that of $M$ - bis-QAC compounds}

We investigated how the alkyl chain length at $n=6$ to $n=18$ of 4 DTBP-X, $n, 4 B C A P-P, n$ and 4PABP-P,n affects bactericidal activity (log $\mathrm{MBC}^{-1}$ ), and moreover, compared the activity of their compounds with that of the corresponding M-bis-QACs such as 4DTBP-6,n, D-38-n and D-136-n possessing a methylene group. Figures 3, 4 and 5 indicate the ef-

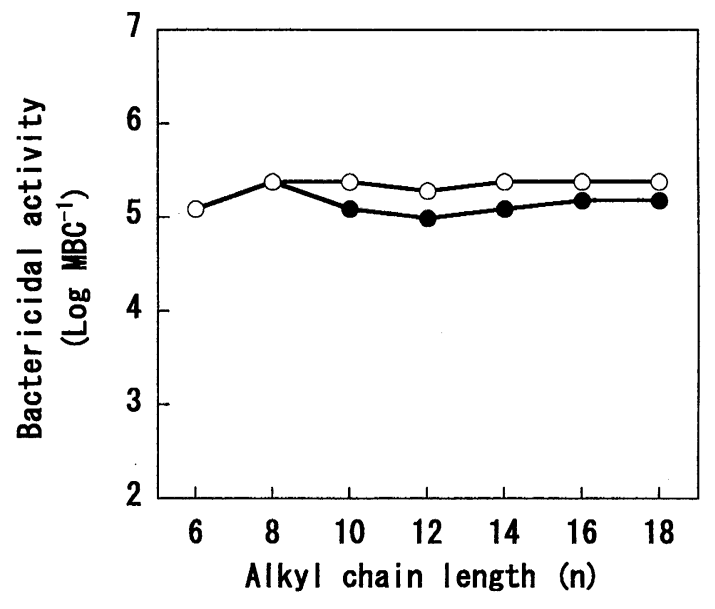

FIG. 3. Effect of alkyl chain length ( $n$ ) on the bactericidal activity $\left(\log \mathrm{MBC}^{-1}\right)$ of $4 \mathrm{DTBP}-\mathrm{X}, \mathrm{n}$ and $4 \mathrm{DTBP}-6, \mathrm{n}$. The unit of MBC is M. Symbols: O, 4DTBP-X,n;, 4 DTBP-6,n.

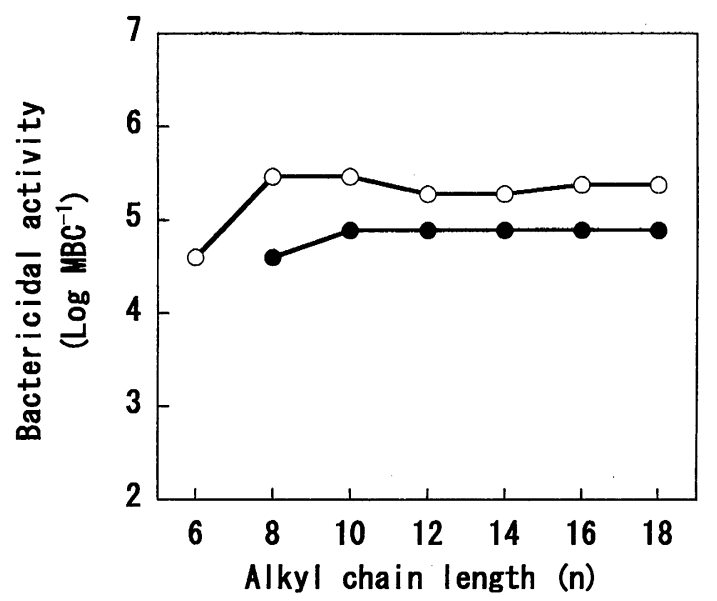

FIG.4. Effect of alkyl chain length $(n)$ on the bactericidal activity $\left(\log \mathrm{MBC}^{-1}\right)$ of $4 \mathrm{BCAP}-\mathrm{P}, \mathrm{n}$ and D-38-n. The unit of MBC is M. Symbols: $O, 4 B C A P-P, n ; 0, D-38-n$. 


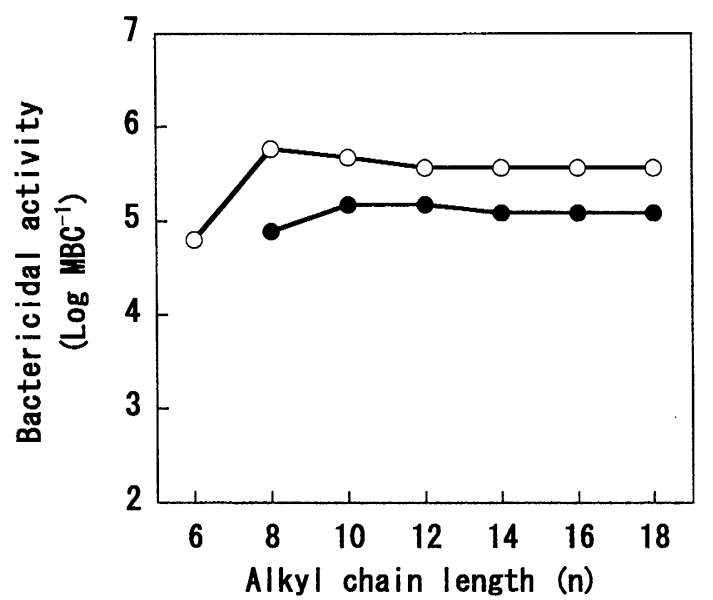

FIG.5. Effect of alkyl chain length ( $\mathrm{n}$ ) on the bactericidal activity $\left(\log \mathrm{MBC}^{-1}\right)$ of $4 \mathrm{PABP}-\mathrm{P}, \mathrm{n}$ and $\mathrm{D}-136-n$. The unit of MBC is M. Symbols: O, 4PABP-P,n; O, D-136-n.

fect of the alkyl chain length on the bactericidal activity of 4DTBP-X,n, 4BCAP-P,n and 4PABP-P, $n$ as Phbis-QACs, and that of 4DTBP-6,n, D-38-n and D-136-n as M-bis-QACs. On the relationship between bacteri- cidal activity and alkyl chain length, the bactericidal activities of Ph-bis-QACs increased with the lengthening from $n=6$ to $n=8$ and were almost constant at $n=8$ to $n=18$. Similarly the M-bis-QACs used for comparison had a regular bactericidal activity at $n=8$ to $n=18$. It has been reported that one of the unique characteristics of bis-QACs is that their bactericidal activities are not affected by alkyl chain length from $n=8$ to $n=18$, and this is different from typical monoQACs such as $N$-alkylpyridinium iodide for which the activity is higher with increasing alkyl chain length (Okazaki et al., 1997). Therefore, the Ph-bis-QACs proved to possess the excellent characteristic of conventional bis-QACs that the bactericidal activity is independent of alkyl chain length $(n=8-n=18)$.

The bactericidal activities of Ph-bis-QACs with a $p$ phenylene group were compared with that of M-bisQACs with a methylene group. Ph-bis-QACs showed higher bactericidal activity than M-bis-QACs at $n=8$ to $n=18$. In the case of 4 DTBP-X,n the activity increased to some degree, and in 4BCAP-P, $n$ and 4PABP-P, $n$ their activities were strengthened especially by converting a methylene group into a $p$ -

TABLE 1. Minimum bactericidal concentrations (MBCs) of 4DTBP-X,8, 4BCAP-P,8, 4PABP-P,8, 4DTBP-6,8, D-38-8 and D136-8 against bacteria.

\begin{tabular}{|c|c|c|c|c|c|c|}
\hline \multirow{3}{*}{ Strain } & \multicolumn{6}{|c|}{$\operatorname{MBC}(\mu M)^{a}$} \\
\hline & \multicolumn{3}{|c|}{ Ph-bis-QACs } & \multicolumn{3}{|c|}{ M-bis-QACs } \\
\hline & $\begin{array}{l}\text { 4DTBP-X, } 8^{b} \\
(4.44)^{n}\end{array}$ & $\begin{array}{l}\text { 4BCAP-P, } 8^{c} \\
(4.72)\end{array}$ & $\begin{array}{l}\text { 4PABP-P, } 8^{d} \\
(4.49)\end{array}$ & $\begin{array}{l}\text { 4DTBP-6, } 8^{\circ} \\
(4.45)\end{array}$ & $\begin{array}{l}\text { D-38-8' } \\
(4.69)\end{array}$ & $\begin{array}{l}\text { D136-8 } \\
(4.42)\end{array}$ \\
\hline $\begin{array}{l}\text { Pseudomonas } \\
\text { aeruginosa ATCC } 27583\end{array}$ & 13 & 6.3 & 6.3 & 25 & $>50$ & 25 \\
\hline $\begin{array}{l}\text { Klebsiella pneumoniae } \\
\text { ATCC } 13883\end{array}$ & 1.6 & 3.1 & 1.6 & 1.6 & 6.3 & 3.1 \\
\hline $\begin{array}{l}\text { Proteus mirabilis } \\
\text { IFO } 3849\end{array}$ & 13 & 6.3 & 6.3 & 13 & $>50$ & 25 \\
\hline $\begin{array}{l}\text { Escherichia coli } \\
\text { K12 W3110 }\end{array}$ & 6.3 & 3.1 & 1.6 & 6.3 & 50 & 13 \\
\hline $\begin{array}{l}\text { Micrococcus luteus } \\
\text { IFO } 12708\end{array}$ & 0.39 & 0.78 & 0.78 & 0.78 & 1.6 & 0.78 \\
\hline $\begin{array}{l}\text { Bacillus cereus } \\
\text { IFO } 3001\end{array}$ & 1.6 & 3.1 & 6.3 & 3.1 & 6.3 & 13 \\
\hline $\begin{array}{l}\text { Staphylococcus aureus } \\
\text { IFO } 12732\end{array}$ & 0.39 & 0.39 & 0.39 & 0.39 & 0.39 & 0.78 \\
\hline $\begin{array}{l}\text { Staphylococcus aureus } \\
\text { IID } 1677 \text { (MRSA) }\end{array}$ & 6.3 & 3.1 & 1.6 & 6.3 & 50 & 6.3 \\
\hline
\end{tabular}

${ }^{a} \mathrm{MBCs}$ were measured by a dilution method using a sterilized water at $30^{\circ} \mathrm{C}$ for $30 \mathrm{~min}$.

${ }^{\circ} 4,4$ '- ( $p$-Xylylenedithio) bis (1-octylpyridinium iodide)s.

${ }^{c} N, N$ '-p-Phenylenebis (1-octyl-4-carbamoylpyridinium bromide) s.

${ }^{a} 4,4^{\prime}$ - (Terephthaloylamino) bis (1-octylpyridinium bromide) s.

${ }^{\circ} 4,4$ '-(1,6-Hexamethylenedithio) bis (1-octylpyridinium iodide)s.

' $N, N$ '-Hexamethylenebis (1-octyl-4-carbamoylpyridinium iodide) s.

${ }^{9} 4,4$ '- (Tetramethylenedicarbonyldiamino) bis (1-octylpyridinium iodide) s.

"Parentheses indicate a chemical shift of methylene protons adjacent to ammonium nitrogen. 
phenylene group. The activity of Ph-bis-QACs showed 8 times the activity of M-bis-QACs at the largest. It was suggested that the increase of bactericidal activity in Ph-bis-QACs is attributable to the steric structure in aqueous solution. M-bis-QACs contain some $\mathrm{CH}_{2}$ $\mathrm{CH}_{2}$ bonds in the methylene spacer, and the number of rotation axes in the spacer is 9,9 and 7 on 4DTBP6,n, D-38-n and D-136-n respectively. Therefore the M-bis-QACs with a lot of rotation axes are presumed to be folded and stretched at their methylene spacer chains in aqueous solution, or remain folded, and two ammonium heads approach each other because of the structural flexibility of the methylene group in the spacer chain of M-bis-QACs. It was suggested that the distance between the ammonium heads of M-bisQACs influences their modes of action against bacterial cells and that a change of the distance results in the decrement of bactericidal activity of M-bis-QACs. On the other hand, Ph-bis-QACs have no $\mathrm{CH}_{2}-\mathrm{CH}_{2}$ bond in their spacer chains by converting the methylene group into a $p$-phenylene group. There are 6 rotation axes in their spacer chains in 4DTBP-X,n and 4 in 4BCAP-P, $n$ and 4 PABP-P, $n$, and their number is less than that in the M-bis-QACs. It is difficult to fold Ph-bis-QACs at their spacer chains in aqueous solution because there are few rotation axes, and a constant distance is kept between ammonium heads. That is, Ph-bis-QACs have are a stable and rigid structure. Therefore, the steric structure property of Ph-bis-QACs which is responsible for the rigid structure was suggested to give a higher bactericidal activity than the activity of M-bis-QACs. It is implied that the bactericidal activity of a bis-QAC is associated with the steric structural factors such as the number of rotation axes and the distance between ammonium heads, and that these factors could be used to find the optimal structure of a bis-QAC.

\section{Antimicrobial characteristics of Ph-bis-QAC de- rivatives}

4DTBP-X,8, 4BCAP-P, 8 and 4PABP-P, 8 as Ph-bisQACs with the alkyl chain at $n=8$ showed the highest bactericidal activity among those with the alkyl chain at $n=6$ to $n=18$. Three Ph-bis-QACs $(n=8)$ were evaluated for the antimicrobial activity against gramnegative bacteria (4 strains), gram-positive bacteria (4 strains) and fungi (6 strains) and were compared with three M-bis-QACs $(n=8)$ such as 4DTBP-6,8, D38-8 and D-136-8.

MBCs against species of bacteria are shown in Table 1. Three Ph-bis-QACs, 4DTBP-X,8, 4BCAP-P,8 and 4PABP-P, 8 exhibited a wide antibacterial spectrum and a strong antibacterial activity against all bacteria. Bis-QACs have been reported with the outstanding characteristic of possessing a strong antibacterial activity regardless of whether the bacteria are gram-negative or positive (Maeda et al., 1999a, and 1999b; Okazaki et al., 1997; Yoshida et al., 2000 and 2001). As seen in Table 1, three Ph-bis-QACs exhibited that characteristic. Therefore, the Ph-bis-QACs proved to possess the same antibacterial characteristics as bis-QACs, and characteristics were supposed to result from the unique structure of bis-QACs having two ammonium cations and two long alkyl chains per

TABLE 2. 'H-NMR data for 4DTBP-X,8, 4BCAP-P,8, 4PABP-P,8, 4DTBP-6,8, D-38-8 and D136-8.

\begin{tabular}{|c|c|}
\hline bis-QACs & 'H-NMR $\left(\mathrm{CD}_{3} \mathrm{OD}\right) \delta^{a}$ \\
\hline 4DTBP-X, $8^{b}$ & $\begin{array}{l}0.89(6 \mathrm{H}, \mathrm{t}, J=6.8) ; 1.30-1.36(20 \mathrm{H}, \mathrm{m}) ; 1.95(4 \mathrm{H}, \mathrm{m}) ; 4.44(4 \mathrm{H}, \mathrm{t}, J=7.4) ; 4.58(4 \mathrm{H}, \mathrm{s}) ; 7.53 \\
(4 \mathrm{H}, \mathrm{s}) ; 7.88(4 \mathrm{H}, \mathrm{d}, J=7.3) ; 8.61(4 \mathrm{H}, \mathrm{d}, J=7.3)\end{array}$ \\
\hline 4BCAP-P, $8^{c}$ & $\begin{array}{l}0.90(6 \mathrm{H}, \mathrm{t}, J=6.8) ; 1.30-1.42(20 \mathrm{H}, \mathrm{m}) ; 2.08(4 \mathrm{H}, \mathrm{m}) ; 4.72(4 \mathrm{H}, \mathrm{t}, J=7.6) ; 7.85(4 \mathrm{H}, \mathrm{s}) ; 8.56 \\
(4 \mathrm{H}, \mathrm{d}, J=6.8) ; 9.21(4 \mathrm{H}, \mathrm{d}, J=6.8)\end{array}$ \\
\hline 4PABP-P, $8^{d}$ & $\begin{array}{l}0.90(6 \mathrm{H}, \mathrm{t}, J=6.8) ; 1.31-1.39(2 \mathrm{HH}, \mathrm{m}) ; 2.00(4 \mathrm{H}, \mathrm{m}) ; 4.49(4 \mathrm{H}, \mathrm{t}, J=7.6) ; 8.23(4 \mathrm{H}, \mathrm{s}) ; 8.42 \\
(4 \mathrm{H}, \mathrm{d}, J=7.4) ; 8.81(4 \mathrm{H}, \mathrm{d}, J=7.3)\end{array}$ \\
\hline 4DTBP-6, $8^{e}$ & $\begin{array}{l}0.89(6 \mathrm{H}, \mathrm{t}, J=7.0) ; 1.30-1.37(20 \mathrm{H}, \mathrm{m}) ; 1.61(4 \mathrm{H}, \mathrm{m}) ; 1.83(4 \mathrm{H}, \mathrm{m}) ; 1.96(4 \mathrm{H}, \mathrm{m}) ; 3.30(4 \mathrm{H}, \\
\mathrm{t}, J=7.4) ; 4.45(4 \mathrm{H}, \mathrm{t}, J=7.4) ; 7.86(4 \mathrm{H}, \mathrm{d}, J=7.3) ; 8.60(4 \mathrm{H}, \mathrm{d}, J=7.3)\end{array}$ \\
\hline D-38-8 & $\begin{array}{l}0.90(6 \mathrm{H}, \mathrm{t}, J=6.8) ; 1.30-1.40(20 \mathrm{H}, \mathrm{m}) ; 1.48(4 \mathrm{H}, \mathrm{m}) ; 1.69(4 \mathrm{H}, \mathrm{m}) ; 2.05(4 \mathrm{H}, \mathrm{m}) ; 3.46(4 \mathrm{H}, \\
\mathrm{t}, J=7.1) ; 4.69(4 \mathrm{H}, \mathrm{t}, J=7.7) ; 8.42(4 \mathrm{H}, \mathrm{d}, J=6.3) ; 9.16(4 \mathrm{H}, \mathrm{d}, J=6.6)\end{array}$ \\
\hline D136-8 & $\begin{array}{l}0.89(6 \mathrm{H}, \mathrm{t}, J=6.8) ; 1.30-1.36(20 \mathrm{H}, \mathrm{m}) ; 1.79(4 \mathrm{H}, \mathrm{m}) ; 1.94(4 \mathrm{H}, \mathrm{m}) ; 2.60(4 \mathrm{H}, \mathrm{m}) ; 4.42(4 \mathrm{H}, \\
\mathrm{t}, J=7.4) ; 8.14(4 \mathrm{H}, \mathrm{d}, J=7.3) ; 8.69(4 \mathrm{H}, \mathrm{d}, J=7.6)\end{array}$ \\
\hline
\end{tabular}

${ }^{a} \mathrm{H}$-NMR spectra were measured in $\mathrm{CD}_{3} \mathrm{OD}$ with a NMR spectrometer (JEM-EX400, 400MHz, JOEL, Tokyo), using tetramethylsilane as an internal standard.

${ }^{b} 4,4$ '- ( $p$-Xylylenedithio) bis (1-octylpyridinium iodide) s.

${ }^{c} N, N$ '- $p$-Phenylenebis (1-octyl-4-carbamoylpyridinium bromide) $s$.

${ }^{\circ} 4,4^{\prime}$ - (Terephthaloylamino) bis (1-octylpyridinium bromide) s.

${ }^{e} 4,4$ '-(1,6-Hexamethylenedithio) bis (1-octylpyridinium iodide) s.

' $N, N$ '-Hexamethylenebis (1-octyl-4-carbamoylpyridinium iodide) s.

${ }^{g} 4,4$ '- (Tetramethylenedicarbonyldiamino) bis (1-octylpyridinium iodide) s. 
TABLE 3. Minimum inhibitory concentrations (MICs) of 4DTBP-X,8, 4BCAP-P,8, 4PABP-P,8, 4DTBP-6,8, D-38-8 and D136-8 against fungi.

\begin{tabular}{|c|c|c|c|c|c|c|}
\hline \multirow{3}{*}{ Strain } & \multicolumn{6}{|c|}{$\operatorname{MIC}(\mu \mathrm{M})^{a}$} \\
\hline & \multicolumn{3}{|c|}{ Ph-bis-QACs } & \multicolumn{3}{|c|}{ M-bis-QACs } \\
\hline & 4DTBP-X, $8^{b}$ & 4BCAP-P, $8^{c}$ & 4PABP-P, $8^{d}$ & 4DTBP- $6,8^{\circ}$ & D-38-8' & D136- $8^{g}$ \\
\hline $\begin{array}{l}\text { Penicillium funiculosam } \\
\text { IFO } 6345\end{array}$ & 1.6 & 1.6 & 3.1 & 0.78 & 12.5 & 3.1 \\
\hline $\begin{array}{l}\text { Chaetomium globosum } \\
\text { IFO } 6347\end{array}$ & 0.78 & 3.1 & 1.6 & 0.78 & 6.3 & 0.78 \\
\hline $\begin{array}{l}\text { Aureobasidium } \\
\text { pullulans IFO } 6353\end{array}$ & 6.3 & 6.3 & 6.3 & 3.1 & 6.3 & 3.1 \\
\hline $\begin{array}{l}\text { Rhizopus stolonifer } \\
\text { IFO } 4781\end{array}$ & 25 & 25 & 6.3 & 6.3 & 25 & 12.5 \\
\hline $\begin{array}{l}\text { Aspergillus terreus } \\
\text { IFO } 6346\end{array}$ & 12.5 & 25 & 6.3 & 1.6 & 6.3 & 3.1 \\
\hline $\begin{array}{l}\text { Aspergillus niger } \\
\text { IFO } 6341\end{array}$ & 6.3 & 12.5 & 6.3 & 6.3 & 12.5 & 12.5 \\
\hline
\end{tabular}

${ }^{a} \mathrm{MICs}$ were measured by a broth dilution method using Sabouraud broth at $30^{\circ} \mathrm{C}$ for $48 \mathrm{~h}$.

${ }^{\circ} 4,4$ '- ( $p$-Xylylenedithio) bis (1-octylpyridinium iodide)s.

${ }^{c} N, N$ '- $p$-Phenylenebis (1-octyl-4-carbamoylpyridinium bromide) s.

${ }^{\circ} 4,4^{\prime}$ - (Terephthaloylamino) bis (1-octylpyridinium bromide) s.

${ }^{\circ} 4,4$ '- (1,6-Hexamethylenedithio) bis (1-octylpyridinium iodide) s.

$' N, N$ '-Hexamethylenebis (1-octyl-4-carbamoylpyridinium iodide)s.

${ }^{9} 4,4$ '-(Tetramethylenedicarbonyldiamino) bis (1-octylpyridinium iodide)s.

molecule. In general, mono-QACs such as $\mathrm{N}$ alkylpyridinium salt and benzyldimethyldodecylammonium chloride are effective against gram-positive bacteria, but not too effective against gram-negative bacteria (Okazaki et al. 1997). Mono-QACs have only one ammonium cation and long alkyl chain per molecule.

The antibacterial activities of three Ph-bis-QACs were greater increased than those of three M-bisQACs against all strains. As described in the above section, it was conjectured that the rigid structure of Ph-bis-QACs contributed to the strength of the antibacterial activity of a bis-QAC. Comparative merits of three M-bis-QACs were found in their antibacterial activities: 4DTBP-6,8 and D-136-8 had the almost same effect, but the effect of D-38-8 was inferior to the two. It was suggested that the electron density of ammonium nitrogen atom in the pyridine ring is influenced by the difference of the relative electron-withdrawing activity of thiol (-S-), carbamoyl (-CONH-) and iminocarbonyl (-NHCO-) groups $p$-cross-linked on the pyridinium salts, and that the difference of electron density results in the comparative merits of the antibacterial activities among the three. It has been published that the bactericidal effect of $N$-dodecylpyridinium derivatives is closely concerned with the electron density of the ammonium nitrogen atom which can be represented by a chemical shift of methylene protons adjacent to ammonium nitrogen (Okazaki et al., 1996). The bactericidal effect of pyridinium salts increases as the electron density is high, namely as the chemical shift of methylene protons adjacent to ammonium nitrogen changes to a high-magnetic field. Table 2 indicates the chemical shifts of methylene protons of each bis-QAC. The chemical shifts of 4DTBP-6,8, D-38-8 and D-136-8 were $4.45,4.69$ and $4.42 \mathrm{ppm}$, respectively, and the tendency corresponded to the merit of their antibacterial activities. On the other hand, Ph-bis-QACs had the almost same activities but the chemical shifts of methylene protons of 4DTBP-X,8, 4BCAP-P, 8 and 4PABP-P, 8 were $4.44,4.72$ and $4.49 \mathrm{ppm}$ respectively. Their activities were not dependent on the electron density of ammonium nitrogen. It was suggested that the rigid structure of a molecule is a more significant factor influencing the antibacterial activity of a bis-QAC than the electron density of ammonium nitrogen.

Table 3 shows MICs against 6 fungi. The Ph-bisQACs proved to have a strong antifungal activity and a wide antifungal spectrum. Their activities were stronger than those of commercial fungicides such as 2-(4-thiazolyl) benzimidazole which has a MIC from 9.7 to $311 \mu \mathrm{M}$ against fungi (Shirai et al., 2002). The antifungal activities of Ph-bis-QACs and M-bis-QACs were almost the same, and the rigid structure of Ph- 
bis-QACs did not result in the increase of antifungal activity by introducing the $p$-phenylene group at their spacer chains. These results led to the conclusion that the structural property of Ph-bis-QACs, the rigid structure, showed a significant efficacy for their bactericidal activities against bacteria and had little effect on their antifungal activities against fungi. It was implied that the differences between the cell surfaces of bacteria and conidia affected the antimicrobial activities of Ph-bis-QACs. However the comparative study on the antibacterial activities of Ph-bis-QAC and Mbis-QACs showed that the high antibacterial activity of Ph-bis-QACs can be attributed to the number of rotation axes in the spacer chain rather than the electron density of ammonium nitrogen, and their rigid structural property. The steric structure of a bis-QAC controlled by the spacer structure was suggested to have a significant effect on the antibacterial activity of a bis-QAC.

\section{REFERENCES}

Baley, G. J., Peck, G. E., and Banker, G. S. (1977) Bactericidal properties of quaternary ammonium compounds in dispersed systems. J. Pharm. Sci., 66, 696-699.

Devinsky, F., Lacko, I., Mlynarcik, D., Racansky, V., and Krasnec, L. (1985) Relationship between critical micelle concentrations and minimum inhibitory concentrations for some non-aromatic quaternary ammonium salts and amine oxides. Tenside Deterg., 22, 10-15.

Devinsky, F., Masarova, L., Lacko, I., and Mlynarcik, D. (1991) Structure-activity relationships of "soft" quaternary ammonium amphiphiles. J. Biopharm. Sci., 2, 1-10.

Devinsky, F., Zamocka, J., Lacko, I., and Polakovicova, M. (1996) QASR and CAMM study of amphiphilic antimicrobially active 2,2'-bipyridylmonoammonium salts. Pharmazie, 51, 727-731.

Diz, M., Manresa, A., Pinazo, A., Erra, P, and Infante, M. R. (1996) Synthesis, surface active properties and antimicrobial activity of new bis-quaternary ammonium compounds. J. Chem. Soc. Perkin Trans. 2, 1871-1876.

Kourai, H., Hasegawa, Y., and Wada, K. (1994) Bactericidal characteristics of $\mathrm{N}$-alkyl-4-butenylpyridinium bromides. $J$. Antibact. Antifung. Agents, 22, 653-661.

Kourai, H., Manabe, Y., Matsutani, E., Hasegawa., Y., and Nakagawa, K. (1995) Antimicrobial activities of alkylallyldimethylammonium iodides and alkylallyldiethylammonium iodides. J. Antibact. Antifung. Agents, 23, 271-280.

Maeda, T., Okazaki, K., Nagamune, H., Manabe, Y., and Kourai, H. (1998) Bactericidal action of 4,4'-( $\alpha, \omega-$ polymethylenedithio) bis (1-alkylpyridinium iodide)s. Biol. Pharm. Bull., 21, 1057-1061.

Maeda, T., Manabe, Y., Yamamoto, M., Yoshida, M.,
Okazaki, K., Nagamune, H., and Kourai, H. (1999a) Synthesis and antimicrobial characteristics of novel biocides, 4,4'-(1,6-hexamethylenedioxdicarbonyl) bis (1alkylpyridinium iodide)s. Chem. Pharm. Bull., 47, 10201023.

Maeda, T., Yoshida, M., Manabe, Y., Okazaki, K., Nagamune, H., and Kourai, H. (1999b) Synthesis and antimicrobial characteristics of 5,5'-[2,2'-(tetramethylenedicarbonyldiox) diethyl] bis(3-alkyl-4-methylthiazolium iodide) s. Biocontrol Sci., 4, 75-81.

Menger, F. M., and Keiper, J. S. (2000) Gemini surfactants. Angew. Chem. Int. Ed., 39, 1906-1920.

Menger, F. M., and Littau, C. A. (1993) Gemini surfactants: a new class of self-assembling molecules. J. Am. Chem Soc., 115, 10083-10090.

Okazaki, K., Manabe, Y., Maeda, T., Nagamune, H., and Kourai, H. (1996) Quantitative structure-activity relationship of antibacterial dodecylpyridinium iodide derivatives. Biocontrol Sci., 1, 51-59.

Okazaki, K., Maeda, T., Nagamune, H., Manabe, Y., and Kourai, H. (1997) Synthesis and antimicrobial characteristics of $4,4^{\prime}-(\alpha, \omega$-polymethylenedithio) bis (1alkylpyridinium iodide) s. Chem. Pharm. Bull., 45, 19701974.

Perez, L., Torres, J. L., Manresa, A., Solan, C., and Infante, M. R. (1996) Synthesis, aggregation and biological properties of a new class of gemini cationic amphiphilic compounds from arginine, bis(Args). Langmuir, 12, 52965301.

Perez, L., Pinazo, A., Rosen, M. J., and Infante, M. R. (1998) Surface activity properties at equilibrium of novel gemini cationic amphiphilic compounds from arginine, bis (Args). Langmuir, 14, 2307-2315.

Perez, L., Garcia, M. T., Ribosa, I., Vinardell, M. P., Manresa, A., and Infante, M. R. (2002) Biological properties of arginine-based gemini cationic surfactants. Environ. Toxicol. Chem., 21, 1279-1285.

Shirai, A., Maeda, T., Hara, I., Nagamune, H., and Kourai, H. (2002) Synthesis and antimicrobial characteristics of 4,4', 4"-(1,2,3-propylenetrithio) tris (1-alkylpyridinium iodide) s. Biocontrol Sci., 7, 55-61.

Yoshida, M., Maeda, T., Okazaki, K., Nagamune, H., Kunikata, K., Tsuchiya, H., Namba, T., and Kourai, H. (2000) Synthesis and antimicrobial characteristics of $N, N^{\prime}$-hexamethylenebis (4-carbamoyl-1-decylpyridinium bromides). Biocontrol Sci., 5, 65-71.

Yoshida, M., Maeda, T., Okazaki, K., Nagamune, H., Kunikata, K., Tsuchiya, H., Namba, T., and Kourai, H. (2001) Synthesis of 4,4'-(tetramethylenedicarbonyldiamino) bis (1-decylpyridinium bromide) and its antimicrobial and deodorant characteristics. Biocontrol Sci., 6, 75 $-80$.

Zana, R., and Talmon, Y. (1993) Dependence of aggregate morphology on structure of dimeric surfactants. Nature, 362, 228-230. 